\title{
PRODUKSI KOMPONEN DARAH PACKED RED CELLS BUFFY COAT REMOVED (PCR BCR) DI UDD PMI KOTA SURAKARTA
}

\author{
Production Of Blood Components Packed Red Cells Buffy Coat Removed (PCR \\ BCR) At PMI UDD Surakarta City \\ Repsi Komaretno ${ }^{1}$, Danik Riawati ${ }^{2}$ \\ Prodi Diploma Tiga Teknologi Bank Darah Politeknik Akbara Surakarta \\ riawatidanik81@gmail.com
}

\begin{abstract}
ABSTRAK
Latar Belakang: Pengolahan komponen darah merupakan suatu tindakan memisahkan komponen darah donor melalui proses dengan memperhatikan kualitas dan keamanan produk komponen darah.

Tujuan penelitian: Untuk mengetahui gambaran produksi komponen darah Packed Red Cells Buffy Coat Removed (PCR BCR) di UDD PMI Kota Surakarta . Metode: Jenis penelitian ini merupakan penelitian deskriptif dengan pendekatan cross sectional. Populasi yang digunakan adalah produksi PRC-BCR di UDD PMI Kota Surakarta bulan Oktober - Desember tahun 2019 sebanyak 288 kolf. Sampel penelitian ini sebanyak 158 kolf. Teknik pengambilan sampel menggunakan purposive sampling. Pengumpulan data menggunakan data sekunder berupa data produksi $P R C-B C R$ di UDD PMI Kota Surakarta bulan Oktober - Desember tahun 2019. Teknik pengolahan data dengan cara editing, coding, data entry dan melakukan teknik analisis. Analisa data menggunakan Analisa univariat yang disajikan dalam bentuk tabel distribusi frekuensi.

Hasil: Produksi komponen darah $P R C-B C R$ sebanyak158 kolf, Produksi $P R C$ $B C R$ berdasarkan golongan darah A rhesus positif sebanyak 53 kolf (34\%), B rhesus positif 45 kolf (28\%), O rhesus positif 48 kolf (30\%), AB rhesus positif 12 kolf $(8 \%)$.

Simpulan: Produksi $P R C-B C R$ di UDD PMI Kota Surakarta bulan Oktober Desember tahun 2019 dengan jumlah 158 kolf. Produksi terbanyak pada bulan Oktober $34 \%$ dan produksi $P R C-B C R$ terbanyak pada golongan darah A rhesus positif $34 \%$.
\end{abstract}

Kata Kunci: Produksi, Komponen, Packed Red Cells Buffy Coat Removed (PCR $B C R)$

\section{ABSTRACT}

Background: The processing of blood components is an act of separating the components of donor blood through a process by taking into account the quality and safety of blood component products. 
Research purposes: to know the description of the production of blood components Packed Red Cells Buffy Coat Removed (PCR BCR) at UDD PMI Surakarta City.

Methods: This type of research is a descriptive study with a cross sectional approach. The population used was the production of PRC-BCR at UDD PMI Surakarta City from October to December 2019 as many as 288 kolf. The research sample was 158 kolf. The sampling technique used purposive sampling. Data collection uses secondary data in the form of PRC-BCR production data at the UDD PMI Surakarta City from October to December 2019. Data processing techniques are editing, coding, data entry and performing analysis techniques. Data analysis using univariate analysis which is presented in the form of a frequency distribution table.

Results: Production of PRC-BCR blood components as much as 158 kolf, Production of PRC-BCR based on blood group A rhesus positive as much as 53 kolf (34\%), B rhesus positive 45 kolf (28\%), $O$ rhesus positive 48 kolf (30\%), $A B$ positive rhesus $12 \mathrm{kolf}$ (8\%.

Conclusion: Production of PRC-BCR at UDD PMI Surakarta City from October to December 2019 with a total of 158 kolf. The highest production was in October $34 \%$ and the highest PRC-BCR production was in blood group A Rhesus positive $34 \%$.

Keywords: Production, Components, Packed Red Cells Buffy Coat Removed (PCR BCR)

\section{PENDAHULUAN}

Menurut WHO bahwa ketersediaan darah di Indonesia minimal sebesar 2\% dari jumlah penduduk, data menunjukan bahwa UTD PMI di seluruh Indonesia mengolah darah sebanyak $72,7 \%$ jumlah donasi darah menjadi komponen darah seperti Packed Red Cell (PRC) (68,50\%), Washed Erythrocytes (WE) (0,90\%), Thrombocyte Concentrate (TC) (20,40\%), Plasma (3.20\%), Fresh Frozen Plasma (FFP) $(6.30 \%)$ dan cryoprecipitate $(0,80 \%)$ (Infodatin, 2018).

Berdasarkan hal tersebut maka diperlukan adanya pemantauan supaya dapat mengukur kebutuhan darah harus seimbang dengan permintaan pasien. Kebutuhan darah seseorang berbeda-beda sesuai dengan advis dokter. Salah satu contoh kebutuhan komponen darah Packed Red Cell Leukoreduced. Pengolahan komponen darah memiliki beberapa manfaat antara lain pasien memperoleh hanya komponen darah yang diperlukan, mengurangi reaksi transfusi, mengurangi reaksi volume transfusi, meningkatkan efisiensi penggunaan darah, memungkinkan penyimpanan komponen darah pada temperatur yang optimal.

Pengolahan komponen darah adalah tindakan memisahkan komponen darah donor dengan prosedur tertentu menjadi komponen darah yang siap pakai. Proses tersebut memperhatikan kualitas dan keamanan. Pemisahan komponen darah harus dilakukan dengan cara aseptik, menggunakan kantong darah ganda, kantong darah triple ataupun kantong darah quadriple dan juga kantong darah tunggal dengan "transfer bag" (Maharani dkk, 2018). Produk darah yang umumnya 
tersedia di Unit Donor Darah (UDD) Palang Merah Indonesia (PMI) adalah Packed Red Cell (PRC) Leukoreduced dengan metode sentrifugasi dan penghapusan Buffy Coat Removed yang di kenal dengan (PRC-BCR) (Menkes RI, 2015). Penelitian terdahulu oleh Alamsyah. A dkk tahun 2018 menyimpulkan bahwa terdapat hubungan positif antara masa simpan darah lebih dari 14 hari dengan kejadian reaksi tranfusi febril non hemolitik.

Studi pendahuluan yang dilakukan dengan melakukan wawancara dengan petugas di UDD PMI Kota Surakarta didapatkan bahwa produksi komponen darah yang dilakukan sesuai dengan permintaan (PMI, 2020). Berdasarkan uraian di atas, maka penulis tertarik mengambil judul "Gambaran Produksi Komponen Darah Packed Red Cell Leukoreduced di UDD PMI Kota Surakarta”. Tujuan Umum penelitian ini adalah untuk mengetahui gambaran produksi komponen darah Packed Red Cell Leukoreduced di UDD PMI Kota Surakarta .

\section{METODE}

Jenis penelitian ini merupakan penelitian deskriptif dengan pendekatan cross sectional. Populasi yang digunakan adalah produksi PRC-BCR di UDD PMI Kota Surakarta bulan Oktober - Desember tahun 2019 sebanyak 288 kolf. Sampel penelitian ini sebanyak 158 kolf. Teknik pengambilan sampel menggunakan purposive sampling. Pengumpulan data menggunakan data sekunder berupa data produksi PRC-BCR di UDD PMI Kota Surakarta bulan Oktober - Desember tahun 2019. Teknik pengolahan data dengan cara editing, coding, data entry dan melakukan teknik analisis., Analisa data menggunakan Analisa univariat yang disajikan dalam bentuk tabel distribusi frekuensi.

\section{HASIL DAN PEMBAHASAN}

\section{Hasil}

1. Produksi komponen darah Packed Red Cell BCR di UDD PMI Kota Surakarta bulan Oktober - Desember tahun 2019

Tabel 1 Hasil Produksi PRC-BCR Kategori Waktu

\begin{tabular}{lcc}
\hline Bulan & Jumlah & $\%$ \\
\hline Oktober & 54 & 34 \\
November & 52 & 33 \\
Desember & 52 & 33 \\
\hline Total & 158 kolf & 100
\end{tabular}

Sumber : Data Sekunder UDD PMI Kota Surakarta, 2019

Data diatas menunjukkan bahwa jumlah produksi komponen darah PCR-BCR rata-rata sekitar 53/bulan. Produksi bulan Oktober sebanyak 54 kolf (34\%), November 52 kolf (33\%), Desember 52 kolf (33\%). 
2. Penyajian Data berdasarkan Kategori Golongan Darah dan Rhesus

Tabel 2 Kategori Berdasarkan Golongan Darah dan Rhesuss

\begin{tabular}{lcc}
\hline Golongan Darah & $\mathrm{f}$ & $\%$ \\
\hline A Rhesus Positif & 53 & 34 \\
B Rhesus Positif & 45 & 28 \\
O Rhesus Positif & 48 & 30 \\
AB Rhesus Positif & 12 & 8 \\
\hline & 158 kolf & 100
\end{tabular}

Sumber : Data Sekunder UDD PMI Kota Surakarta, 2019

Berdasarkan tabel diatas didapatkan bahwa dari produksi komponen darah PCR-BCR spaling banyak yaitu golongan darah A rhesus positif berjumlah 53 kolf $(34 \%)$, dan paling sedikit golongan darah $\mathrm{AB}$ rhesus positif berjumlah 12 kolf $(8 \%)$.

\section{Pembahasan}

Hasil penelitian didapatkan bahwa pada tabel 1 menunjukkan bahwa produksi bulan Oktober sebanyak 54 kolf (34\%), November 52 kolf (33\%), Desember 52 kolf (33\%). berdasarkah hasil tersebut dapat disimpulkan bahwa rata-rata produksi komponen darah PRC-BCR rata-rata sekitar 53/bulan. Menurut teori bahwa PRCBCR atau PRC Leukoreduced adalah sel darah merah yang jumlah leukositnya sudah dikurangi dengan memisahkan lapisan buffy coat. PRC-BCR diproses secara otomatisasi dengan sistem kantong darah Top and Bottom (TB). Hal tersebut maka dapat dilihat produksi komponen disesuaikan dengan permintaan pasien, karena tidak dapat menyimpan terlalu lama (Menkes, 2015).

Menurut teori aspek kualitas dan keamanan harus terjamin untuk mendapatkan produk yang baik dan aman. Contohnya proses pemisahan komponen darah harus dilakukan dengan cara aseptik, menggunakan kantong darah ganda, kantong darah triple ataupun kantong darah quadriple dan juga kantong darah tunggal dengan "transfer bag" (Maharani, dkk, 2018). Produk darah Packed Red Cells (PRC) Leukoreduced dengan metode sentrifugasi dan penghapusan Buffy Coat Removed yang di kenal dengan (PRC-BCR) umumnya tersedia di Unit Transfusi Darah (UTD) Palang Merah Indonesia . PRC-BCR disimpan pada suhu $2^{\circ} \mathrm{C}$ sampai $6^{\circ} \mathrm{C}$, dengan suhu transportasi antara $2^{\circ} \mathrm{C}$ dan $10^{\circ} \mathrm{C}$ untuk maksimal 24 jam. Masa simpan PRC-BCR 42 hari karena menggunakan antikoagulan SAGM (Saline, Adenin, Glukosa, Manitol) (Menkes RI, 2015). Hal ini didukung oleh penelitian aragih P., Adhayanti, I., Lubis, Z., Hariman, H. 2019 yang menyimpulkan bahwa PCR yang disimpa selama 7 hari masih layak dipergunakan, terjadi penurunan pada plasma glukosa namun masih dalam batas normal.

Penelitian ini sejalan dengan penelitian Srihartaty dkk tahun 2014 yang menyatakan bahwa terdapat penurunan jumlah leukosit yang bermakna pada komponen PRC yang dimodifikasi dengan metode bed-side leucocyte filtration selama $<48$ ja dibandingkan metode buffy-coat depleted. Tidak ditemukan perbedaan kadar sitokin IL-6 dan TNF- pada kedua metode produk darah. 
Menurut Kamilah, D dkk tahun 2019 yang menyimpulkan bahwa kejadian reaksi transfusi FNHTR lebih rendah pada pasien yang mendapat transfusi PRC Leukodepleted (14 pasien) dibandingkan dengan pasien yang mendapat transfusi PRC non Leukodepleted (121 pasien), sehingga PRC Leukoreduced terbukti mengurangi kejadian reaksi transfusi.

Tabel 2 menunjukkan bahwa produksi komponen darah Packed Red Cell (PRC) BCR paling banyak yaitu golongan darah A rhesus positif berjumlah 53 kolf (34\%), dan paling sedikit golongan darah $\mathrm{AB}$ rhesus positif berjumlah 12 kolf (8\%). Menurut teori manfaat klinis penggunaan PRC Leukoreduced adalah untuk mengurangi frekuensi dan tingkat keparahan Reaksi Transfusi Febrile non hemolytic transfusion reaction (FNHTRs). menurut Karl Landstainer bahwa setiap individu mempunyai karakteristik golongan darah yang berbeda yaitu golongan darah $\mathrm{A}, \mathrm{B}$, dan $\mathrm{O}$. Sistem golongan darah $\mathrm{ABO}$ terdiri atas Ag yang utama terdapat di membran sel darah merah dan $A b$ yang secara alamiah terbentuk sejak lahir. Seseorang dengan golongan darah $\mathrm{ABO}$ dan $\mathrm{AB}$ harus mempunyai $\mathrm{Ag} \mathrm{H}$ dan $\mathrm{Ag} \mathrm{H}$ terdapat pada golongan darah $\mathrm{O}$ (Maharani, dkk, 2018).

Hal ini sesuai dengan Dispermadesdukcapil di Jawa Tengah di dapatkan data bahwa golongan darah di Kota Surakarta golongan darah $A_{+}$sekitar 2232 dan A- 35, golongan darah O- 810 dan $\mathrm{O}+192$, golongan darah $\mathrm{B}_{+} 356$ dan $\mathrm{B}-53$, golongan darah $\mathrm{AB}_{+} 260$ dan $\mathrm{AB}-91$.

\section{SIMPULAN DAN SARAN}

\section{Simpulan}

Produksi komponen darah PRC-BCR bulan Oktober - Desember tahun 2019 diperoleh sebanyak 158 kolf, Produksi komponen darah PRC-BCR paling banyak yaitu golongan darah A rhesus positif yaitu $34 \%$

\section{Saran}

Bagi peneliti selanjutnya diharapkan sebelum melakukan produksi komponen darah PRC-BCR harus melihat stok darah agar stok darah seimbang antara permintaan dan pembuatan sehingga darah yang telah dibuat tidak ada yang kadaluarsa

\section{DAFTAR PUSTAKA}

Alamsyah. A, Widyaningrum D \& KZL Edward, 2018. "Hubungan masa simpan packed Red Cell dengan kejadian febrile haemolytic transfusion reaction (FNHTRs)". Jurnal Media Medika Muda Volume 3 Nomor 1. https://ejournal2.undip.ac.id/index.php/mmm/article/view/5952.

Dispermadesdukcapil, 2020. Open Data Kependudukan Dispermadesdukcapil Provinsi Jawa Tengah. https://dispermadesdukcapil.jatengprov.go.id/eppid/index.php/data/kategori/?id=4\# 
Infodatin, Pusat Data dan Informasi Kementerian Kesehatan RI, 2018. Pelayanan Darah di Indonesia

Kamilah D dan Widyaningrum, 2019. Hubungan Jenis Packed Red Cell Yang Ditranfusikan Dengan Reaksi Tranfusi Febrile Non Haemolytic Transfusion Reaction (FNTHTR). Jurnal Intisari Sains Medis Volume 10 Nomor 1. https://isainsmedis.id/index.php/ism/article/view/348.

Menkes, 2015. Peraturan Menteri Kesehatan Republik Indonesia Nomor 91 Tahun 2015 Tentang Standar Pelayanan Transfusi Darah. https://www.kemhan.go.id/itjen/2017/03/13/peraturan-menteri-kesehatanrepublik-indonesia-nomor-91-tahun-2015-tentang-standar-pelayanantransfusi-darah.html

Maharani, E, A, dan Noviar, G, 2018, “Imunohematologi Dan Bank Darah", pusat pendidikan sumber daya manusia kesehatan, Jakarta

PMI, 2020. Data PMI Kota Surakarta

Saragih P., Adhayanti, I., Lubis, Z., Hariman, H. 2019. "Pengaruh waktu simpan Packed Red Cells (PRC) terhadap perubahan kadar hemoglobin, hematokrit, dan glukosa plasma di RSUP H. Adam Malik, Medan, Indonesia. Intisari Sains Medis Volume 10 Nomor 2. https://isainsmedis.id/index.php/ism/article/view/415.

Srihartaty, Yuyun Siti Maryuningsih Soedarmono, Pustika Amalia Wahidiyat, , 2014. Perbedaan Penurunan Jumlah Leukosit dan Sitokin pada Packed-Red Cell dengan Metode Buffy-Coat Depleted dan Modifikasi Bed-Side Leucocyte Filtration. J Indon Med Assoc, Volume: 64, Nomor: 10, Oktober 2014. http://mki.idionline.org/index.php?uPage=magazine.magazine_article\&smod $=$ magazine $\& \mathrm{sp}=$ public \&iddata $=24$ 